\title{
The Uncovered Interest Rate Parity Anomaly And Foreign Exchange Market Turnover
}

John F. Boschen, Ph.D., The College of William and Mary, USA

Kimberly J. Smith, Ph.D., The College of William and Mary, USA

\begin{abstract}
The uncovered interest rate parity (UIP) anomaly is that high interest rate currencies appreciate, rather than depreciate, against low interest rate currencies. We show that the UIP anomalies apparent in six major currency pairs have diminished over our 1995-2010 sample period. We further show that the observed decline in deviations from UIP is associated with the substantially higher transaction volume now present in the foreign exchange markets. We interpret our findings as consistent with the proposition that the UIP anomaly dissipates as the foreign exchange markets become more efficient.
\end{abstract}

Keywords: Uncovered Interest Rate Parity; Foreign Exchange Market Turnover

\section{INTRODUCTION}

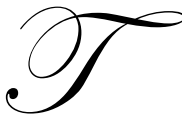

he central prediction of uncovered interest rate parity (UIP) is that higher interest rate currencies depreciate against lower interest rate currencies. However, the failure of this prediction to hold empirically has been documented by many studies. ${ }^{1}$ Indeed, empirical studies often find the reverse; low interest rate currencies seem to depreciate against high interest rate currencies. This reverse finding is often referred to as the UIP anomaly or puzzle.

This paper builds on the suggestion by Flood and Rose (2002) that deviations in UIP may change as foreign exchange markets become more efficient or "deepen." 2 We provide empirical findings that are consistent with the proposition that the UIP anomaly has moderated as the foreign exchange markets have grown in terms of both overall liquidity and in trading by firms that seek to arbitrage deviations in UIP.

A salient feature of the foreign exchange markets in recent years has been the large increase in trading turnover. Importantly, much of the growth in turnover has been due to the entrance of non-dealer financial firms into the market. Non dealer financial firms (i.e. mutual funds, hedge funds, currency funds, pension funds and other non-dealer financial firms) were a counterparty in almost one-half of all foreign exchange transactions in 2010, up from only a quarter of all transactions in $1995 .^{3}$ Because turnover growth reflects both improved liquidity and the increased presence of additional participants in the foreign exchange markets, we propose that foreign exchange market turnover is a good candidate for a proxy variable for market deepening.

The first task in this paper is to show that the UIP anomaly has in fact diminished over time in the six major currency pairs we examine. The second task is to use the foreign exchange market turnover data that is available over the 1995-2010 sample period to examine whether there is an empirical link between the diminution of the UIP anomaly and increased turnover in the foreign exchange markets.

\footnotetext{
${ }^{1}$ See Sarno (2005) for a review of the empirical literature on testing UIP.

${ }^{2}$ Flood and Rose (2002), p.253.

${ }^{3}$ Triennial Central Bank Survey: Report on Global Foreign Exchange Market Activity in 2010, BIS, Table B.2.
} 


\section{EMPIRICAL ANALYSIS}

\section{The UIP Anomaly in the Major Currencies}

We focus our analysis on six major currencies, the Australian dollar (AUD), Canadian dollar (CAD), Swiss franc (CHF), Euro (EUR), British pound (GBP), and the Japanese yen (JPY) paired against the U.S. dollar (USD). These currency pairs generate the overwhelming volume of foreign exchange transactions activity so that deviations in UIP associated with these currencies are especially important to study. In addition because these currencies are so widely used in foreign exchange deals, there is consistent data on currency-specific transactions going back to 1995.

The standard empirical formulation for testing whether UIP holds is:

$\Delta \mathrm{S}_{\mathrm{t}+1}=\alpha+\beta\left(\mathrm{i}_{\mathrm{t}}-\mathrm{i}_{\mathrm{t}} *\right)+\varepsilon_{\mathrm{t}+1}$

Applied to our empirical analysis, $\Delta \mathrm{S}_{\mathrm{t}+1}$ is the 3-month log difference in the exchange rate in USDs per unit of foreign currency, $\mathrm{i}_{\mathrm{t}}$ and $\mathrm{i}_{\mathrm{t}}{ }^{*}$ are the 3-month domestic currency and foreign currency interest rates, respectively. Under the null hypothesis that UIP holds, $\alpha=0$ and $\beta=1 .^{4}$

Table 1, panels A and B, contain estimates of $\beta$ for the six currencies for the early and later halves of our sample, respectively. The early sample period regressions in panel A show the classic UIP anomaly; the $\beta$ coefficients on the interest rate spread in these regressions are negative and statistically significant in most cases.

Table 1, panel B, replicates panel A for the latter half of the sample period. The negative, significant $\beta$ coefficients reported in panel A are no longer apparent. In five of the six currency regressions the estimated $\beta$ is positive. Wald tests (not shown) of the null hypothesis that $\beta=1$ could not reject the null in four (CAD, CHF, EUR and GBP) of the six cases. We now investigate whether market turnover is linked to these observed changes in the $\beta$ coefficients.

Table 1

UIP Regressions ${ }^{\text {a }}$

\begin{tabular}{|c|c|c|c|}
\hline \multicolumn{4}{|c|}{$\begin{array}{l}\text { Panel A } \\
\text { 1995:04-2002:10 }\end{array}$} \\
\hline \multicolumn{4}{|c|}{$\Delta S_{k, t+1}=\alpha_{k}+\beta_{k}\left(i_{t}-i_{t}^{*}\right)+\varepsilon_{k, t+1}$} \\
\hline Currency & $\beta$ & $\sigma_{\beta}$ & $\mathbf{R}^{2}$ \\
\hline AUD & $-6.1702^{b}$ & 1.4016 & .179 \\
\hline CAD & $-1.7021^{\mathrm{c}}$ & 0.8975 & .039 \\
\hline $\mathrm{CHF}$ & $-5.1771^{b}$ & 1.4922 & .118 \\
\hline EUR/DM & $-4.8014^{b}$ & 1.3780 & .124 \\
\hline GBP & $-3.7140^{b}$ & 1.3436 & .079 \\
\hline JPY & -1.6438 & 2.1146 & .007 \\
\hline \multicolumn{4}{|c|}{$\begin{array}{l}\text { Panel B } \\
\text { 2002:11 -2010:06 }\end{array}$} \\
\hline \multicolumn{4}{|c|}{$\Delta \mathrm{S}_{\mathrm{k}, \mathrm{t}+1}=\alpha_{\mathrm{k}}+\beta_{\mathrm{k}}\left(\mathrm{i}_{\mathrm{t}}-\mathrm{i}_{\mathrm{t}}^{*}\right)+\varepsilon_{\mathrm{k}, \mathrm{t}+1}$} \\
\hline Currency & $\beta$ & $\sigma_{\beta}$ & $\mathbf{R}^{2}$ \\
\hline AUD & $5.2017^{b}$ & 2.2589 & .056 \\
\hline CAD & 0.7067 & 2.2863 & .001 \\
\hline $\mathrm{CHF}$ & 0.6873 & 1.6142 & .002 \\
\hline EUR/DM & 1.9766 & 1.7317 & .014 \\
\hline GBP & $3.8024^{\mathrm{c}}$ & 1.8302 & .046 \\
\hline JPY & -1.0931 & 1.1541 & .010 \\
\hline
\end{tabular}

${ }^{\mathrm{a}}$ The $\Delta \mathrm{S}_{\mathrm{k}, \mathrm{t}+1}$ is the 3-month change in the log exchange rate for the $\mathrm{k}^{\text {th }}$ currency. $\mathrm{i}$ and $\mathrm{i}^{*}$ are the 3-month LIBORs for the USD and the foreign currency, respectively. The observation frequency is monthly. $\sigma$ is the standard error. The standard errors were estimated using the Newey-West (1987) estimator to correct for the moving average error term introduced by overlapping observations. The data were supplied by Bloomberg, the British Bankers Association, and the Federal Reserve Bank of St. Louis FRED database. The Deutsch mark (DM) was used in the EUR regressions for 1995-1999.

${ }^{\mathrm{b}}$ Significant at the 1 percent level.

${ }^{\mathrm{c}}$ Significant at the 5 percent level.

${ }^{4}$ Because the focal point of most empirical tests of UIP has been on $\beta$, we suppress reporting the $\alpha$ 's for brevity. In the reported regressions, the $\alpha$ coefficients were not significantly different than zero in almost all cases. 


\section{Foreign Exchange Market Turnover Data}

For this study we constructed an intertemporally-consistent data series of trend foreign exchange market turnover over the 1995 - 2010 period. The Bank for International Settlements (BIS) triennial central bank surveys of foreign exchange market turnover are a primary source for foreign exchange turnover data. The BIS reports turnover as the total U.S. dollar (USD) value of currency deals made during the month of April of the survey year regardless of whether settlement of the deal occurred after the end of the month. A given foreign exchange transaction is reported to the BIS as the nominal currency value of the deal converted to USDs at the exchange rate that prevailed at the time of the deal. For example, a dealer who buys British pounds (GBPs) reports the buy amount converted to USDs and the dealer that sold the GBPs reports the sale amount converted to USDs. The doublecounting that results from one dealer reporting the buy leg and another dealer reporting the sell leg of the same transaction is netted out to arrive at total average daily turnover. Total turnover includes not only spot and outright forward turnover but turnover from foreign exchange swaps and exercised options. For this study we had available the data from the 1995, 1998, 2001, 2004, 2007, and 2010 BIS surveys.

There are two adjustments to the nominal BIS turnover data that are needed to make it comparable on an intertemporal basis. These are, first, adjusting for the effect of changing exchange rates on turnover reported in USDs, and second, adjusting for the impact of the introduction of the EUR in January 2000 and the associated disappearance of transactions between the ECU currencies.

Figure 1

Unadjusted BIS USD-Denominated Turnover and Exchange-Rate-Adjusted BIS Turnover $1995-2010$

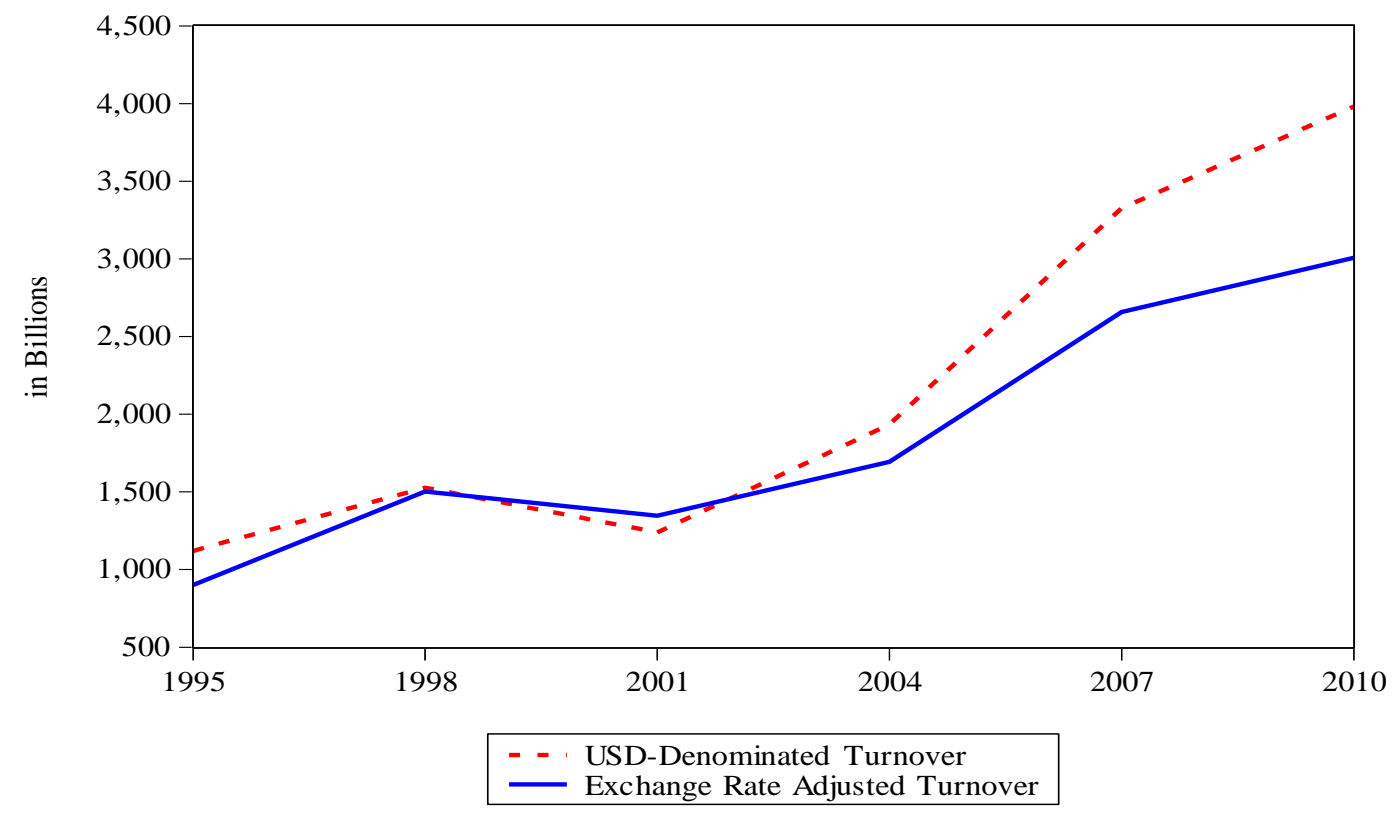

Adjusting for changes in exchange rates is necessary because a change in the value of the USD relative to other currencies will alter reported total turnover volume whenever non USD transactions are converted to USDs. Other things equal, a trend depreciation in the USD relative to the other major currencies will increase the reported USD value of turnover, thus putting an upward bias in the turnover data. We correct for this bias by scaling the USD turnover data by the trade-weighted USD exchange rate index. ${ }^{5}$ The trade-weighted index is effectively units

\footnotetext{
${ }^{5}$ The Trade Weighted Exchange Rate Index of Major Currencies, TWEXMMTH, is computed by the Board of Governors of the Federal Reserve System. The currencies in the index pertain to the Euro Area, Canada, Japan, United Kingdom, Switzerland,
} 
of weighted currencies per USD and so deflates the increases in the nominal value of USD turnover due solely to depreciation in the USD. Figure 1 shows the effect of this adjustment on the BIS turnover data. The adjusted series displays slower growth reflecting the upward bias in the USD turnover data associated with the post-2001 trend depreciation in the USD against the other currencies.

The introduction of the EUR had two consequences for turnover volume. The obvious consequence was that transactions between the pre-EUR ECU currencies, such as the French franc and the Italian lira, went away. The less obvious consequence was that the volume of external transactions between the EUR and the other major vehicle currencies declined relative to the combined external transactions of the separate ECU currencies. ${ }^{6}$

Table 2 shows the percentage of total turnover associated with the DM and the other ECU currencies in 1998 and the total turnover associated with the EUR in 2001. Based on the exchange rate adjusted total turnover of 1998, the data in table 2 imply that the EUR's introduction caused an approximately 224 billion USD decline in trading volume. ${ }^{7}$ We revised down the 1998 total turnover volume by this amount and revised the 1995 total turnover down by 224 billion times the ratio of 1995 to 1998 total turnover to account for the fact that total turnover was lower in 1995. The main effect of the adjustment for introduction of the EUR is to lower somewhat the 1995 and 1998 turnover, and the overall impact of both adjustments is to lower actual turnover relative to the nominal turnover data. The adjusted turnover data were converted to monthly data series using the implied monthly growth rates computed over each of the periods between surveys.

Table 2

Impact of Introduction of the Euro on Foreign Exchange Market Turnover

\begin{tabular}{|l|c|c|c|}
\hline & \multicolumn{2}{|c|}{ Percent Shares of Average Daily Turnover } & $\begin{array}{c}\text { Implied Turnover Volume } \\
\text { (in Billions) }\end{array}$ \\
\hline CurrencylYear & $\mathbf{1 9 9 8}$ & $\mathbf{2 0 0 1}$ & 564.75 \\
\hline EUR & - & 37.6 & 452.10 \\
\hline DM & 30.1 & - & 336.45 \\
\hline Other ECU Currencies & 22.4 & - & -223.80 \\
\hline
\end{tabular}

${ }^{\text {a }}$ Source: Triennial Central Bank Survey: Foreign Exchange and Derivatives Markets Activity in 2001, BIS, Table B.4.

${ }^{\mathrm{b}}$ Based on an exchange rate adjusted USD average daily total turnover of 1.502 trillion in 1998.

The LIBORs for the six currencies were used to construct interest rate spreads for each currency against the USD that correspond to the three-month LIBOR funding periods. ${ }^{8}$ Daily data on spot exchange rates were used to construct log differences in spot rates matched to the LIBOR three-month funding periods. The observation frequency is monthly for all series so the three-month funding period data overlap and must be adjusted for in the empirical analysis using the standard Newly and West (1987) correction. The data series run from April 1995 through April 2010.

\section{Estimated Effect of Turnover on UIP}

We focus on a simple linear model of $\beta$ embedded in equation (1):

$\Delta \mathrm{S}_{\mathrm{t}+1}=\alpha+\beta_{\mathrm{t}}\left(\mathrm{i}_{\mathrm{t}}-\mathrm{i}_{\mathrm{t}} *\right)+\varepsilon_{\mathrm{t}+1}$

where $\beta_{\mathrm{t}}=v+\gamma$ TOTTRN $_{\mathrm{t}}$.

Australia and Sweden. The index is measured as weighted units of foreign currency per USD with $1973=100$. The peak value of the index during our sample period, 108.7, occurred in April 2001 and the lowest value, 75.6, occurred in April 2010.

${ }^{6} \mathrm{Hau}$ et al.(2002) associate the decline in external transactions with higher transactions costs in early-on trading in the EUR.

${ }^{7}$ Hau et al. (2002) calculate a 193 billion USD decline in trading volume due to the EUR. The difference in estimates is due to our use of subsequently revised turnover data for 1998 and 2001 and the adjustment for exchange rate changes.

${ }^{8}$ LIBOR funding periods differ slightly from month to month due to value, settlement and maturity dating conventions. 
TOTTRN $_{\mathrm{t}}$ is average daily total turnover, and $v$ and $\gamma$ are the coefficients to be estimated.

Table 3, panel A contains the estimates of $v$ and $\gamma$ using aggregate total market turnover as the explanatory variable. The $\gamma$ coefficients are positive and significant. Panel B of table 3 replicates panel A with currency-specific turnover replacing aggregate turnover. Again the $\gamma$ coefficients are positive and are statistically significant in five of six cases.

Table 3

Effect of Foreign Exchange Turnover on UIP 1995:04-2010:06

\begin{tabular}{|c|c|c|c|c|c|}
\hline \multicolumn{6}{|c|}{$\begin{array}{l}\text { Panel A } \\
\text { Aggregate Turnover }\end{array}$} \\
\hline \multicolumn{6}{|c|}{$\begin{array}{c}\Delta \mathrm{S}_{\mathrm{k}, \mathrm{t}+1}=\alpha_{\mathrm{k}}+\beta_{\mathrm{kt}}\left(\mathrm{i}_{\mathrm{t}}-\mathrm{i}_{\mathrm{t}}{ }^{*}\right)+\mu_{\mathrm{k}, \mathrm{t}+1} \\
\beta_{\mathrm{kt}}=v_{\mathrm{k}}+\gamma_{\mathrm{k}} \text { TOTTRN } \mathrm{T}_{\mathrm{t}}\end{array}$} \\
\hline Currency & $v$ & $\sigma_{v}$ & $\gamma$ & $\boldsymbol{\sigma}_{\gamma}$ & $\mathbf{R}^{2}$ \\
\hline AUD & $-10.4558^{b}$ & 4.6102 & 0.0041 & 0.0026 & .079 \\
\hline CAD & $-13.9133^{b}$ & 4.7985 & $0.0084^{b}$ & 0.0036 & .089 \\
\hline $\mathrm{CHF}$ & $-6.6710^{b}$ & 2.1127 & $0.0030^{b}$ & 0.0010 & .093 \\
\hline EUR/DM & $-14.8544^{b}$ & 3.1842 & $0.0077^{\mathrm{b}}$ & 0.0020 & .160 \\
\hline GBP & $-13.0696^{b}$ & 5.3802 & $0.0074^{\mathrm{b}}$ & 0.0031 & .157 \\
\hline JPY & $-4.3250^{b}$ & 1.8955 & $0.0019^{c}$ & 0.0008 & .063 \\
\hline \multicolumn{6}{|c|}{$\begin{array}{l}\text { Panel B } \\
\text { Currency-Specific Turnover }\end{array}$} \\
\hline \multicolumn{6}{|c|}{$\begin{aligned} \Delta \mathrm{S}_{\mathrm{k}, \mathrm{t}+1} & =\alpha_{\mathrm{k}}+\beta_{\mathrm{kt}}\left(\mathrm{i}_{\mathrm{t}}-\mathrm{i}_{\mathrm{t}}{ }^{*}\right)+\mu_{\mathrm{k}, \mathrm{t}+1} \\
\beta_{\mathrm{kt}} & =v_{\mathrm{k}}+\gamma_{\mathrm{k}} \text { TOTTRN }_{\mathrm{kt}}\end{aligned}$} \\
\hline Currency & $v$ & $\sigma_{v}$ & $\gamma$ & $\boldsymbol{\sigma}_{\gamma}$ & $\mathbf{R}^{2}$ \\
\hline AUD & -6.5943 & 2.9720 & 0.0335 & 0.0261 & .057 \\
\hline CAD & $-10.9358^{b}$ & 3.6563 & $0.1593^{\mathrm{c}}$ & 0.0690 & .085 \\
\hline $\mathrm{CHF}$ & $-7.4164^{b}$ & 2.1300 & $0.0478^{\mathrm{b}}$ & 0.0157 & .102 \\
\hline EUR/DM & $-15.1574^{b}$ & 3.2447 & $0.0211^{\mathrm{b}}$ & 0.0056 & .162 \\
\hline GBP & $-9.6520^{b}$ & 5.1402 & $0.0386^{\mathrm{c}}$ & 0.0206 & .098 \\
\hline JPY & $-6.2152^{b}$ & 2.4214 & $0.0146^{\mathrm{b}}$ & 0.0067 & .075 \\
\hline
\end{tabular}

${ }^{\mathrm{a}}$ The TOTTRN is aggregate total turnover. TOTTRN $\mathrm{N}_{\mathrm{k}}$ is total turnover for currency $\mathrm{k}$. The data were supplied by the BIS, Bloomberg, the British Bankers Association, regional Foreign Exchange Committees and the Federal Reserve Bank of St. Louis FRED database.

${ }^{\mathrm{b}}$ Significant at the 1 percent level.

${ }^{c}$ Significant at the 5 percent level.

The positive values of the $\gamma$ coefficients imply that growth in turnover volume can least partly explain the split-sample findings in Table 1. That is, as turnover volume increases there is an evolution in the $\beta_{\mathrm{t}}$ coefficients, initially negative early on, to the more positive values of $\beta_{\mathrm{t}}$ in the later part of the sample. To see how foreign exchange turnover growth impacted the $\beta$ coefficient in equation (1) over time we estimated the six currency equations as an SUR model and used the resulting estimates of $v$ and $\gamma$ to simulate the value of $\beta$ over time. Specifically the empirical model of $\beta$ from the SUR is $\beta_{t}=-4.793+.001842 \cdot$ TOTTRN $_{t}$. The simulation results are shown in Figure 2. The values of the $\beta_{\mathrm{t}}$ coefficients using these estimates of $v$ and $\gamma$ indicate that the value of $\beta$ starts with the classic negative sign associated with the UIP anomaly in the early sample and approaches unity as the volume of foreign exchange turnover increases in the post 2001 part of the sample. 
Figure 2

Simulation of $\beta$ Coefficient in Equation (1) from SUR Estimation

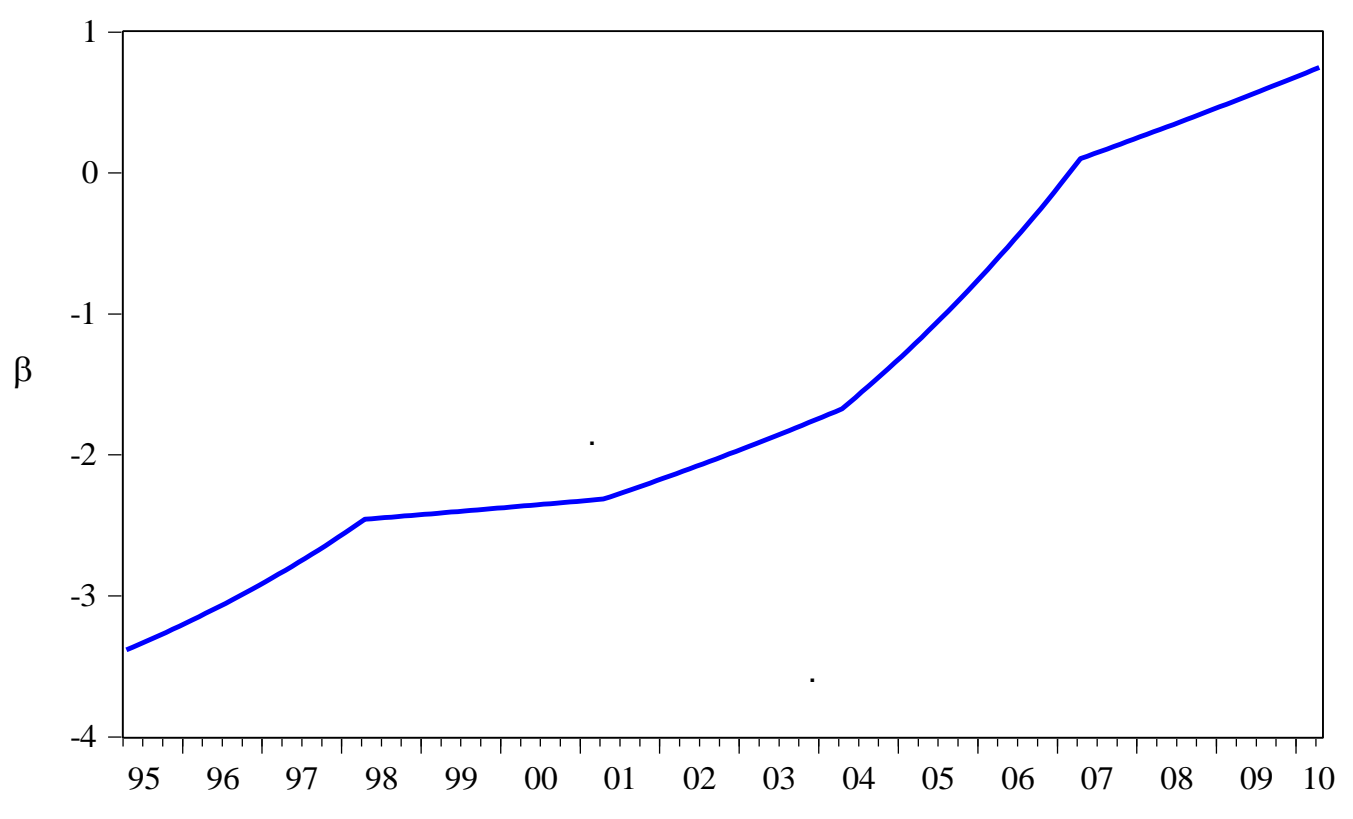

\section{CONCLUSION}

The empirical tests support the proposition that the observed mitigation of the UIP anomaly in six major currency pairs is related to our proxy variable for foreign exchange market deepening or efficiency. One interpretation of these results is that the high levels of turnover volume, in part due to more participation by non dealer financial entities, signals a more efficient market in the sense that possible impediments to foreign exchange market arbitrage (i.e., suggested by Bacchetta and Van Wincoop (2010), Hochradl and Wagner (2010) and others) are now less important.

\section{AUTHOR INFORMATION}

John F. Boschen is Brinkley-Mason Professor of Economics and Finance at The College of William and Mary. He completed his PhD in Economics at Brown University in 1981. He was an economist at the Federal Reserve Board, and has been Visiting Scholar at the Federal Reserve Banks of Kansas City and Richmond. His research interests include business cycles, monetary policy, and inflation risk, and he has published over two dozen articles in such respected journals as the Journal of Business, Journal of Money Credit and Banking, the Journal of Monetary Economics and The Accounting Review. E-mail: john.boschen@mason.wm.edu. Corresponding author.

Kimberly J. Smith is Associate Professor and KPMG Accounting Fellow at The College of William and Mary. She completed her Ph.D. in Business Administration at the University of Maryland in 1989. In 2003-2004, she served as the Academic Accounting Fellow at the Office of the Chief Accountant of the U.S. Securities and Exchange Commission. Her research interests include CEO pay and performance, and off-balance sheet arrangements, and she has published a number of articles in leading journals such as The Accounting Review, Journal of Business, Accounting Organizations and Society, Journal of Management Accounting Research, and Issues in Accounting Education. E-mail: kim.smith@mason.wm.edu. 


\section{REFERENCES}

1. Bacchetta, P. and Van Wincoop, E. (2010). Infrequent Portfolio Decisions: A Solution to the Forward Rate Puzzle. American Economic Review. 100(3), 870-904.

2. Bank for International Settlements (2011). Triennial Central Bank Survey of Foreign Exchange and Derivative Market Activity in 2010. Basle, Switzerland.

3. Flood, R.P. and Rose, A.K., (2002). Uncovered Interest Rate Parity in Crisis. IMF Staff Papers. 49(2), 252266.

4. Hau, H., Killeen, W., Moore, M., Honohan, P., Franks, J., and Portes, R., (2002). How Has the Euro Changed the Foreign Exchange Market? Economic Policy. 17(34), 149-191.

5. Hochradl, M. and Wagner, C., (2010). Trading the Forward Bias: Are there Limits to Speculation? Journal of International Money and Finance. 29(3), 423-441.

6. Newey, W.K., and West, K.D., (1987). A Simple, Positive Definite, Heteroskedasticity and Autocorrelation Consistent Covariance Matrix. Econometrica. 55(3), 703-708.

7. Sarno, L., (2005). Viewpoint: Towards a Solution to the Puzzles in Exchange Rate Economics: Where Do We Stand? Canadian Journal of Economics. 38(3), 673-708. 
NOTES 